\title{
Cryptococcal antigenemia among HIV seropositive patients accessing care in antiretroviral therapy (ART) clinics in Calabar, South Southern Nigeria
}

Ofonime M. Ogba* and Lydia Abia-Bassey

*Corresponding author: ofonimemark@yahoo.com

Department of Medical Laboratory Science, University of Calabar, Nigeria.

\begin{abstract}
Background: Cryptococcus neoformans infection is a life threatening disease especially when associated with immunosupression like HIV/AIDS. The greatest burden of disease occurs in subSaharan Africa, where mortality is estimated to be $17 \%$. The finding of cryptococcal antigen in the blood represents a condition of systemic invasion with the fungus. Clinical manifestation of infection with Cryptococcus neoformans in AIDS patients is generally more evident at CD4 cells $\leq 100$ cells $/ \mu$. This study was carried out to determine cryptococcal antigenemia among HIV seropositive patients accessing care in ART clinics as patients are not screened routinely despite reports of relatively high co-infection rates with HIV.
\end{abstract}

Methods: This prospective cross-sectional study was carried out on ART-treated and ART-naive HIV positive adult patients attending ART clinics in two tertiary hospitals in Calabar, Nigeria. The seroprevalence of cryptococcal antigen among the patients was determined using the cryptococcal antigen latex agglutination system (CALAS) (Wampole Laboratories, USA), according to the manufacturer's instruction. The CD4 count levels of each patient were determined by flow cytometry using the fluorescent activated cell sorter BD FACS Count system (Becton Dickinson).

Results: Out of the 272 HIV positive subjects enrolled in the study, 116(42.6\%) were ARV-naïve and 156(57.4\%) were ARV-treated patients. A 5.1\% cryptococcal antigenemia prevalence was established in the study. Infection rates were higher among subjects receiving ART 11/156 (7.1\%) than in ARTnaïve subjects $3 / 116(2.6 \%)$. Infection rates $5(35.7 \%)$ peaked at age $25-34$ years. The mean CD4 counts of subjects with cryptococcal infection were $100.7 \pm 67.8 \mathrm{cells} / \mu \mathrm{l}$, with a minimum CD4 count of 13.0. All the infections occurred among subjects with CD4 counts $\leq 200$ cells/ $\mu$ l of blood. There was a statistically significant effect of cryptococcal antigenemia on the CD4 counts of the subjects $(t=3.7$, $\mathrm{p}=0.002$ ).

Conclusion: This study reveals that cryptococcal antigenemia is a health problem among HIV/ AIDS patients in our locality. Cryptococcal antigenaemia seem to be more common among HIV patients on ART. The CD4 count levels among the ART treated subjects could have been boosted by administration of ART

Keywords: Cryptococcal antigen, HIV/AIDS patients, CD4 counts, antiretroviral therapy (ART)

\section{Introduction}

Cryptococcosis is one of leading pulmonary and meningeal mycoses of worldwide occurrence. It causes an estimated one million cases of cryptococcal meningitis per year among HIV/
AIDS patients resulting in nearly 625,000 deaths [1]. The greatest burden occurs in Sub-Saharan Africa, where mortality is estimated to be $17 \%[\mathbf{2 , 3}]$.

The disease predominantly occurs in immunocompromised 
patients with underlying predisposing factors, such as advanced HIV disease, organ transplantation, haematological malignancies and aggressive cancer therapy $[\mathbf{4 , 5}]$. It is a disease that has become the focus of the attention in Europe, America, Africa, and Southeast Asian countries [6,7]. Prior to the availability of highly active antiretroviral treatment (HAART), the disease was considered the fourth major cause of mortality in individuals with AIDS [1]. Extrapulmonary cryptococcosis is an AIDS-defining illness. The most frequent clinical presentation is disseminated meningoencephalitis which is rapidly fatal in the absence of antifungal treatment $[\mathbf{8 , 9}]$.

Cryptococcus neoformans is an encapsulated fungal pathogen [10]. On routine laboratory media, colonies of C. neoformans develop within 36 to 72 hours. Colonies appear as white to cream coloured, with mucoid consistency and may be several millimeters in diameter. Colonies may also develop sectors that differ in pigmentation [11]. The amount of capsule can be judged from the degree of colonial mucosity. Highly encapsulated colonies may coalesce and slowly trickle down a slant to puddle in the bottom of the tube or drip off the medium of inverted plates [12].

Cryptococcus neoformans is a spherical, budding, encapsulated yeast cell in both tissue and culture microscopic examinations. The yeast cells measure between 5 to $10 \mu \mathrm{m}$ in diameter and exist as single and multiple buds [13], but majority of cells in tissue and culture lack buds because they readily detached from their parent cells. On rare occasions, filamentous and short hyphal variants have been isolated [4].

The mode of transmission to humans is by inhalation of basidiospores or dehydrated haploid yeast. These small propagules lodge in the lung alveoli from where they are spread to the central nervous system to cause meningoencephalitis [14-16].

On entry into the lungs, the yeast cells become rehydrated and acquire the characteristic polysaccharide capsule. In the case of basidiospores, these would convert to encapsulate blastoconidia $[17,18]$.

\section{Methods \\ Specimen collection}

Five $\mathrm{ml}$ of blood was collected from all subjects by trained Medical Laboratory scientists and Nurses by venopuncture allowed to clot and centrifuged to obtain serum. This was used to confirm the HIV status of the subjects before enrolling them for the studies using the Determine rapid test kit (Abbott Laboratories, Tokyo, Japan) and STAT-PAK HIV 1/2 assay (Chembio, Medford, NY, USA). A part of the patient's serum was used to determine CD4 counts by flow cytometry using the BD fluorescent-activated cell sorter system (BD Biosciences, San Jose, CA, USA) as per the manufacturer's instructions. The sero-prevalence of cryptococcal antigen in the patients and the control group was measured using the cryptococcal antigen latex agglutination system (CALAS) (Wampole Laboratories, Cranbury, NJ, USA) according to manufacturer's instructions.

\section{Ethical approval}

Ethical approval was obtained from the ethical research committee, UCTH, Calabar, Nigeria. Informed consent was also obtained from all the subjects.

\section{Serology and assessment of immune status}

Serological tests were performed on the serum collected from the patients for cryptococcal antigen detection, using the CryptoLA Test (Wampole Laboratories, New Jersey, USA). The kit is a simple, sensitive, qualitative and semi-quantitative latex test which detects capsular polysaccharide antigens of Cryptococcus neoformans in Serum and cerebrospinal fluid. Samples were initially heat inactivated in a water bath at $56^{\circ} \mathrm{C}$ for 30 minutes to reduce non-specific interference with cryptococcal antigen latex test [19-21]. All tests were carried out according to the manufacturer's instructions. The CD4 counts were determined by flow cytometry using the fluorescent activated cell sorter $\mathrm{BD}$ FACS Count system (Becton Dickinson) as per the manufacturer's instruction [19].

\section{Data analysis}

The data obtained in this study were analyzed with Epi-Info CDC, 2000 and Microsoft excel data analysis packages. Descriptive statistics were carried out. Frequencies were calculated for categorical variables. Interactions between specific categorical clinical variables were tested for significance using the $\mathrm{x}^{2}$ test. Student's $t$ test was used to compare the means between two variables. A p-value of 0.05 was considered statistically significant.

\section{Results}

Out of the 272 HIV positive subjects enrolled in the study, 116(42.6\%) were ARV-naïve while 156(57.4\%) were ARV-treated patients (Table 1). A total of 14(5.1\%) subjects were positive for Cryptococcal antigenaemia (CRAG). The infection rates were higher among subjects receiving ART 11/156 (7.1\%) than in ART-naïve subjects 3/116 (2.6\%). Infection rates 5(35.7\%) peaked at age 25-34 years (Table 1).

Females were more infected than males and had a lower mean CD4 counts $(97.7 \pm 64.9$ cells $/ \mu \mathrm{l})$ than males $(112.0 \pm 92.4$ cells/ $\mu$ l) (Table 2).

The mean CD 4 count of subjects with cryptococcal infection was $100.7 \pm 67.8$ while those without cryptococcal infections had a mean CD4 count of $355.8 \pm 253.1$. All the infections occurred among subjects with CD4 counts $\leq 200$ cells/ $\mu$ lof blood. There was a statistically significant association between Cryptococcus infection and the CD4 counts of the subjects $(t=3.7, p=0.002)$ (Table 3).

Table 4 shows the comparative mean CD4 counts of ARTnaïve and ART-treated subjects. The ART-naive subjects had a lower mean CD4 count $(71.3 \pm 47.5$ cells $/ \mu \mathrm{l})$ than the ARTtreated subjects $(108.8 \pm 72.1$ cells/ $\mu \mathrm{l})$. There was a statistically significant difference in mean CD4 counts between the two groups $(t=3.25, \mathrm{p}=0.001)$. 
Ogba et al. Microbiology Discovery 2015,

http://www.hoajonline.com/journals/pdf/2052-6180-3-7.pdf

doi: $10.7243 / 2052-6180-3-7$

Table 1. Age distribution of cryptococcal antigenemia among subjects.

\begin{tabular}{|c|c|c|c|c|c|c|}
\hline \multirow{2}{*}{$\begin{array}{l}\text { Age } \\
\text { (years) }\end{array}$} & \multicolumn{2}{|c|}{ ART Treated } & \multicolumn{2}{|c|}{ ART Naïve } & \multirow[b]{2}{*}{$\begin{array}{l}\text { Total No. } \\
\text { tested }\end{array}$} & \multirow[b]{2}{*}{$\begin{array}{l}\text { Total No. } \\
\text { (\%) positive }\end{array}$} \\
\hline & No. tested & $\begin{array}{l}\text { No. }(\%) \\
\text { positive }\end{array}$ & No. tested & $\begin{array}{l}\text { No. (\%) } \\
\text { positive }\end{array}$ & & \\
\hline $15-24$ & 22 & $2(9.1)$ & 26 & $0(0.0)$ & $48(17.6)$ & $2(14.3)$ \\
\hline $25-34$ & 60 & $3(5.0)$ & 44 & $2(4.5)$ & $104(38.2)$ & $5(35.7)$ \\
\hline $35-44$ & 40 & $3(7.5)$ & 23 & $1(4.3)$ & $63(23.2)$ & $4(28.6)$ \\
\hline $45-54$ & 24 & $3(12.5)$ & 15 & $0(0.0)$ & $39(14.3)$ & $3(21.4)$ \\
\hline $55-64$ & 8 & $0(0.0)$ & 5 & $0(0.0)$ & $13(4.8)$ & $0(0.0)$ \\
\hline $65-74$ & 2 & $0(0.0)$ & 3 & $0(0.0)$ & $5(1.8)$ & $0(0.0)$ \\
\hline Total & $156(57.4)$ & $11(7.1)$ & $116(42.6)$ & $3(2.6)$ & 272 & $14(5.1)$ \\
\hline
\end{tabular}

Table 2. Comparative mean CD4 counts of subjects positive for cryptococcal antigenaemia by gender.

\begin{tabular}{lllll}
\hline Gender & No. tested & $\begin{array}{l}\text { No. (\%) } \\
\text { positive }\end{array}$ & Mean CD4 counts & Statistics \\
\hline Female & 167 & $11(6.6)$ & $97.7 \pm 64.9$ & $\mathrm{t}=0.31$ \\
Male & 105 & $3(2.9)$ & $112.0 \pm 92.4$ & $\mathrm{p}=0.7$ \\
\hline
\end{tabular}

Table 3. Comparative mean CD4 counts of subjects with and without cryptococcal infections.

\begin{tabular}{llll}
\hline $\begin{array}{l}\text { Cryptococcal } \\
\text { antigenaemia }\end{array}$ & $\begin{array}{l}\text { No. }(\%) \text { of } \\
\text { subjects }(\mathbf{n}=\mathbf{2 7 2})\end{array}$ & Mean CD4 counts & Statistics \\
\hline Positive & $14(5.1)$ & $100.7 \pm 67.8$ & $\mathrm{t}=3.75$ \\
Negative & $258(94.9)$ & $355.8 \pm 253.1$ & $\mathrm{p}=0.002$ \\
\hline
\end{tabular}

Table 4. Comparative mean CD4 counts of ART treated and ART-naïve (HIV/AIDS) subjects with cryptococcal infections.

\begin{tabular}{llll}
\hline $\begin{array}{l}\text { Cryptococcal } \\
\text { antigenaemia }\end{array}$ & ART-treated & ART-naïve & Statistics \\
\hline $\begin{array}{l}\text { No. }(\%) \text { of subjects } \\
\text { Mean CD4 counts }\end{array}$ & $11(7.1)$ & $3(2.6)$ & $\mathrm{t}=1.96, \mathrm{p}=0.05$ \\
\begin{tabular}{l} 
(cells $/ \mu \mathrm{l})$ \\
\hline
\end{tabular} & & $71.3 \pm 47.5$ & $\mathrm{t}=3.25, \mathrm{p}=0.001$ \\
\hline
\end{tabular}

\section{Discussion}

Cryptococcal antigen (CRAG) can be detected weeks before the onset of symptoms, and those who are asymptomatic but positive for cryptococcal antigen have a high risk of subsequent cryptococcal meningitis and mortality [22]. In this study fourteen $(5.1 \%)$ of the study subjects were positive for serum cryptococcal antigen. Mamoojee et al., [23] reported 2\% CRAG prevalence among HIV patients enrolled for antiretroviral therapy in Ghana while Chukwuanukwu et al., [24] reported a $13.1 \%$ cryptococcal antigenemia (CRAG) among HIV positive women attending prevention of mother to child transmission (PMTCT) clinics in South Eastern Nigeria. The higher (5.1\%) prevalence in our study may be due to the fact that Mamoojee and colleagues' [23] enrolled fewer number of subjects in their study. On the other hand, Chukwuanuku and colleagues' [24] higher prevalence (13.1\%) may be due to further depression of immune status by pregnancy among their subjects.

The $(7.1 \%)$ prevalence of serum cryptococcal antigen recorded among ART treated subjects in this study is lower than the $12.2 \%$ reported in Congo, $13.1 \%$ in Thailand and $13.5 \%$ in Kampala, Uganda [25-27]. Also a (2.6\%) serum cryptococcal antigenemia was recorded among ART naive patients. This finding is also lower than the $(12.7 \%)$ prevalence reported in Benin city, Nigeria [28]. The low cryptococcal antigenaemia among our subjects could be due to the significant reduction in HIV burden in Cross River State from 12\% to 6\% between 1994 to 2005 [29]. The massive HIV intervention strategy carried out by Global HIV Initiatives (GHAIN), Presidents Emergency Program for AIDS Relief (PEPFAR) and the World Bank, in the last 15 years in Nigeria and Cross River State in particular has led to this reduction in HIV burden in the State.

Females had more seropositivity $11 / 167$ (6.6\%) for CRAG when compared to their male counterparts $3 / 105$ (2.9\%). The reason could be due to the lower CD4 count levels among females than males. Age did not also play a significant role on serum CRAG positivity among patients $\left(\chi^{2}=2.42, \mathrm{p}=0.49\right)$.

Several studies evaluating the prevalence of serum cryptococcal antigenemia in AIDS patients have reported a consistently higher prevalence of serum CRAG in patients with lower CD4 cell counts [28]. Subjects with cryptococcal antigenaemia had a lower mean CD 4 counts $100.7 \pm 67.8$ cells/ $\mu$ l than the CRAG negative subjects with CD4 count levels of $355.8 \pm 253.1$ cells/ $\mu \mathrm{l}$ of blood. This could reflect further depletion of CD 4 cells by cryptococcal infection among the patients. Cryptococcal antigen (CRAG) screening directed at all newly diagnosed HIV cases with CD 4 counts $\leq 200$ cells/ $\mu$ l is likely to identify patients at risk of developing cryptococcal meningitis.

Cryptococcal antigenaemia seem to be more common among HIV patients on ART. The higher Cryptococcus neoformans infection rates among ART-treated patients than ART-naïve patients could be explained with the fact that some of those subjects just commenced the ART therapy. The mean CD4 counts $108.8 \pm 72.1$ cells/ $\mu$ l among ART-treated patients were also higher than the ART naïve subjects $71.3 \pm 47.5$ cells/ $\mu$ which depicts that the administration of ART could have boosted the 
Ogba et al. Microbiology Discovery 2015,

CD4 count levels among these subjects.

\section{Conclusion}

This study reveals that cryptococcal antigenemia is a health problem among HIV/AIDS patients in our locality. Although cryptococcal antigenaemia was more common among HIV patients on ART, the higher CD4 count levels among them depicts that the administration of ART could have boosted the CD4 count levels among these subjects. Thus, Cryptococcal antigen screening should be made a routine for all HIV positive patients accessing care in ART clinics in Calabar. This will improve the lives of the patients, reduce morbidity and reduce preventable deaths which arise from cryptococcal meningitis.

\section{Recommendation}

Cryptococcal antigen (CRAG) screening is lacking in our institutions, it is necessary to incorporate this as a routine screening test for HIV programme in Calabar and Nigeria in general.

\section{Competing interests}

The authors declare that they have no competing interests.

\section{Authors contributions}

O. Ogba and L. Abia Bassey were involved inthe writing of manuscript and study designing. O. Ogba carried out the laboratory and data analysis and conceived the study.

\section{Acknowlegement}

We are grateful to the management and staff of University of Calabar Teaching Hospital for the use of their subjects and facilities and University of Calabar for the enabling environment for research.

\section{Publication history}

Editor: Fukai Frank Bao, Kunming Medical University, China. Received: 19 January 2015 Revised: 04 March 2015

Accepted: 16 April 2015 Published: 23 April 2015

\section{References}

1. Centre for Disease control and Prevention CDC. Cryptococcosis Statistics. Atlanta, Georgia. 2011.

2. Holmes CB, Losina E, Walensky RP, Yazdanpanah $Y$ and Freedberg KA. Review of human immunodeficiency virus type 1-related opportunistic infections in sub-Saharan Africa. Clin Infect Dis. 2003; 36:652-62. I Article I PubMed

3. Park BJ, Wannemuehler KA, Marston BJ, Govender N, Pappas PG and Chiller TM. Estimation of the current global burden of cryptococcal meningitis among persons living with HIV/AIDS. AIDS. 2009; 23:525-30. | Article | PubMed

4. Casadevall A and Perfect J.R. Cryptococcus neoformans. Washington, DC: ASM Press. 1998.

5. Khan ZU, Randhawa HS, Kowshik T, Chowdhary A and Chandy R. Antifungal susceptibility of Cryptococcus neoformans and Cryptococcus gattii isolates from decayed wood of trunk hollows of Ficus religiosa and Syzygium cumini trees in north-western India. J Antimicrob Chemother. 2007; 60:312-6. | Article | PubMed

6. Mirza SA, Phelan M, Rimland D, Graviss E, Hamill R, Brandt ME, Gardner T, Sattah M, de Leon GP, Baughman W and Hajjeh RA. The changing epidemiology of cryptococcosis: an update from population-based active surveillance in 2 large metropolitan areas, 1992-2000. Clin Infect Dis. 2003; 36:789-94. | Article | PubMed

7. Singh N, Husain S, De Vera M, Gayowski T and Cacciarelli TV.
Cryptococcus neoformans Infection in Patients With Cirrhosis, Including Liver Transplant Candidates. Medicine (Baltimore). 2004; 83:188-92. | Article I PubMed

8. Dupont B, Crewe Brown HH, Westermann K, Martins MD, Rex JH, Lortholary O and Kauffmann CA. Mycoses in AIDS. Med Mycol. 2000; 38 Suppl 1:259-67. I PubMed

9. Mwaba P, Mwansa J, Chintu C, Pobee J, Scarborough M, Portsmouth $S$ and Zumla A. Clinical presentation, natural history, and cumulative death rates of $\mathbf{2 3 0}$ adults with primary cryptococcal meningitis in Zambian AIDS patients treated under local conditions. Postgrad Med J. 2001; 77:769-73. | Article | PubMed Abstract | PubMed FullText

10. Diaz MR and Fell JW. Use of a suspension array for rapid identification of the varieties and genotypes of the Cryptococcus neoformans species complex. J Clin Microbiol. 2005; 43:3662-72. I Article I PubMed Abstract I PubMed FullText

11. Mitchell T. G. Medical mycology. In: G. F. Brooks, J. S. Butel \& S. A. Morse. Jawetz, Melnick and Adelberg's medical microbiology. $23^{\text {rd }}$ edition. Singapore: McGraw Hill. 645-651. 2004.

12. Mitchell TG and Perfect JR. Cryptococcosis in the era of AIDS--100 years after the discovery of Cryptococcus neoformans. Clin Microbiol Rev. 1995; 8:515-48. | Article | PubMed Abstract | PubMed FullText

13. King J.W and Dasgupta A. Cryptococcosis. EMedicine. 2007; 10:1-23.

14. Barchiesi F, Cogliati M, Esposto MC, Spreghini E, Schimizzi AM, Wickes $B L$, Scalise $G$ and Viviani MA. Comparative analysis of pathogenicity of Cryptococcus neoformans serotypes $A, D$ and $A D$ in murine cryptococcosis. J Infect. 2005; 51:10-6. I Article I PubMed

15. Idnurm A, Bahn YS, Nielsen K, Lin X, Fraser JA and Heitman J. Deciphering the model pathogenic fungus Cryptococcus neoformans. Nat Rev Microbiol. 2005; 3:753-64. | Article I PubMed

16. Lin $X$ and Heitman J. The biology of the Cryptococcus neoformans species complex. Annu Rev Microbiol. 2006; 60:69-105. | Article | PubMed

17. Kwong-chung K. J and J.E. Bennet. Cryptococcosis. In: J. E. Kwong-chung \& J. E. Bennett (eds), Medical Mycology. Philadelphia: Lea and Febiger. 1992; 397-446.

18. Buchanan KL and Murphy JW. What makes Cryptococcus neoformans a pathogen? Emerg Infect Dis. 1998; 4:71-83. I Article I PubMed Abstract I PubMed FullText

19. Wadhwa A, Kaur R, Agarwal SK, Jain S and Bhalla P. AIDS-related opportunistic mycoses seen in a tertiary care hospital in North India. $J$ Med Microbiol. 2007; 56:1101-6. I Article I PubMed

20. Hoang LM, Maguire JA, Doyle P, Fyfe M and Roscoe DL. Cryptococcus neoformans infections at Vancouver Hospital and Health Sciences Centre (1997-2002): epidemiology, microbiology and histopathology. J Med Microbiol. 2004; 53:935-40. I Article I PubMed

21. World Health Organization. Blood safety and clinical technology: Guidelines on standard operating procedures for laboratory diagnosis of HIV-opportunistic infections. South East Asia: WHO. 2007. I Pdf

22. Rajasingham R, Meya DB and Boulware DR. Integrating cryptococcal antigen screening and pre-emptive treatment into routine HIV care. J Acquir Immune Defic Syndr. 2012; 59:e85-91. I Article I PubMed Abstract | PubMed FullText

23. Mamoojee Y, Shakoor S, Gorton RL, Sarfo S, Appiah LT, Norman B, Balakrishnan I, Phillips R and Chadwick D. Short Communication: Low seroprevalence of cryptococcal antigenaemia in patients with advanced HIV infection enrolling in an antiretroviral programme in Ghana. Trop Med Int Health. 2011; 16:53-6. I Article I PubMed

24. Chukwuanukwu 1R, Manafa P1, Iloghalu E, Onyenekwe C, Ifeanyichukwu $\mathrm{M}$ and Mbamalu C. Cryptococcus neoformans antigenemia in hiv positive pregnant women attending a pmtct clinic in south east nigeria. Journal of Biology, Agriculture and Healthcare. 2013; 3:18.

25 . Desmet $P$, Kayembe KD and De Vroey $C$. The value of cryptococcal serum antigen screening among HIV-positive/AIDS patients in Kinshasa, Zaire. AIDS. 1989; 3:77-8. I PubMed

26. Liechty CA, Solberg P, Were W, Ekwaru JP, Ransom RL, Weidle PJ, Downing $\mathrm{R}$, Coutinho A and Mermin J. Asymptomatic serum cryptococcal 
Ogba et al. Microbiology Discovery 2015,

http://www.hoajonline.com/journals/pdf/2052-6180-3-7.pdf

antigenemia and early mortality during antiretroviral therapy in rural Uganda. Trop Med Int Health. 2007; 12:929-35. | Article | PubMed

27. Harris JR, Lindsley MD, Henchaichon S, Poonwan N, Naorat S, Prapasiri $P$, Chantra S, Ruamcharoen F, Chang LS, Chittaganpitch M, Mehta N, Peruski L, Maloney SA, Park BJ and Baggett HC. High prevalence of cryptococcal infection among HIV-infected patients hospitalized with pneumonia in Thailand. Clin Infect Dis. 2012; 54:e43-50. | Article | PubMed

28. Osazuwa F, Dirisu JO, Okuonghae PE and Ugbebor O. Screening for cryptococcal antigenemia in anti-retroviral naive AIDS patients in benin city, Nigeria. Oman Med J. 2012; 27:228-31. | Article | PubMed Abstract I PubMed FullText

29. Federal Ministry of Health. Technical report: National HIV/syphilis sero-prevalance sentinels survey among pregnant women attending ante-natal clinics in Nigeria. Lagos: FMH Press. 2005.

\section{Citation:}

Ogba OM and Abia-Bassey L. Cryptococcal antigenemia among HIV seropositive patients accessing care in antiretroviral therapy (ART) clinics in Calabar, South Southern Nigeria. Microbiol Discov. 2015; 3:7.

http://dx.doi.org/10.7243/2052-6180-3-7 